\title{
The Figure of the Translator
}

\author{
Susan Bassnett \\ University of Warwick \\ s.bassnett@warwick.ac.uk
}

\begin{abstract}
This paper, originally given as a lecture at the IWL, considers the fundamental importance of translation in the movement of texts across cultures and questions why it has taken so long for literary criticism to recognise this, despite the growing international interest in translation in the twenty-first century. Through a range of examples, the paper makes the case for translation as a vital force in intercultural communication and as a shaping force in literary history.
\end{abstract}

\section{Keywords}

Translation studies - rewriting - creativity - collaboration

In the summer 2013 issue of the Journal for Literary Translators, In Other Words, the editor Daniel Hahn started his editorial with the statement that: "it does feel to me as though things have changed significantly for the literary translation profession in the last few years" (1). He was, of course, referring to the British context, and things certainly did to need to change in our increasingly monoglot society. The British government under Tony Blair abolished compulsory foreign language learning in English schools in 2004, with predictably dire consequences, and the present coalition government is belatedly trying to repair the damage. (Note, of course, English schools: thankfully there is a bilingual policy in Wales and increasing recognition in Scotland also of both Scots and Gaelic). But I agree with Daniel Hahn—we are seeing more prizes for literary translators, more workshops and book fairs featuring translation, a gradual acknowledgement by reviewers that the name of a translator deserves a mention when a book by a non-English-speaking writer is being discussed, more small publishers venturing boldly to publish translations and, proba- 
bly most significant of all, a growing body of readers who buy translations. Ted Hughes' version of Ovid's Metamorphoses made the British bestseller lists in 1997, as did Seamus Heaney's Beowulf in 1999, a totally unexpected phenomenon.

Within academia, interest in translation has been growing apace, with a proliferation of journals, books, conferences, doctoral dissertations and courses, linked of course to the growth of the relatively new subject, Translation Studies. When I wrote my book Translation Studies in 1980, there was no sense of the field being even in existence. I had to convince Terry Hawkes, editor of the New Accents series in which the book appeared, to take a risk that there might be some interest in studying translation systematically, and he then had to convince the publishers. Yet that book sells more copies today than any of us ever imagined, and the 4th expanded edition was published in 2014, along with a new Chinese edition and a Korean edition.

It is worth noting at this juncture that there was considerable resistance in the 1970 s to all kinds of new fields, especially if they were interdisciplinary: film, media, theatre, women and gender, postcolonial studies were all, like translation studies, regarded by some established disciplines with suspicion. I well remember one Faculty meeting at the University of Warwick where I attempted to introduce an MA course in translation when I was publicly accused of "trying to destroy genuine comparative literature!" (my italics).

Why, then is there such interest in translation today? How can we start to explain it? Translation has been around for millennia; moving between languages is by no means a new concept. Let's imagine a class in fifty years' time, looking at the seeming global rise in interest in translation, both literal and metaphorical, and think about what they might be seeing. For a start, they would probably note that the movement of peoples around the planet since 1980 s was significant. The Berlin Wall came down in 1989, the same year as the Tiananmen Square massacre in China, so after 1989, they would note the collapse of the Soviet bloc, China opening up to the world, apartheid ending in South Africa - all huge political events, to which can be added other factors determining movement, some terrible, such as famine, war, political repression, some commercial, for example, international trade agreements such as the expansion of the European Union, along with cheaper international travel and burgeoning tourism to cater for the new markets, for the millions now able to acquire a passport. Nor will our students of the future forget the rise of globalized merchandising and, of course, the advent of the worldwide web, so they might conclude that as so many more people came to be moving around, one result was an increase in intercultural experiences, and a stronger impulse to learn more about cultural difference. 
Those future students might also note that the world in the twenty-first century was becoming increasingly unstable, with nuclear proliferation, global warming, and great changes in the balance of global power, with the Middle East, Central Asia and North Africa now sites of major conflicts. Emily Apter's splendid book The Translation Zone deals beautifully with the ambiguities and gaps that opened up in the West after 9/11, gaps exacerbated by linguistic and cultural ignorance.

Major political events have epistemological consequences. We need only think of the American and French Revolutions in relation to the movement we term Romanticism to have a prime example of this, or we can think of Turkey, and Kemal Atatürk's revolution of the 1920s that propelled the country towards Europe, employing a strategic cultural translation strategy. For whatever happens in the world, there are consequences and connections. As Matthew Arnold put it, in his 1857 Inaugural lecture in Oxford: "Everywhere there is connection, everywhere there is illustration. No single event, no single literature is adequately comprehended except in relation to other events, to other literatures" (270).

Arnold was writing in the mid-nineteenth century, when railway lines were only starting to creep across the planet, but he could well have been writing that today. Connections are endlessly made, from the profound to the trivial. Whoever would have imagined that a Korean popular musician with a song and dance routine satirizing conspicuous consumption in a particular social group in Seoul in 2012 would have become such a global phenomenon that I recently watched my 3-year-old grand-daughter at a dance class in Yorkshire performing her own version of Gangnam style!

And our students in fifty years' time will most certainly be making more connections, seeing things we perhaps still cannot see because we are living enmeshed in those webs. But I think one of the strands that will become clear in the future is the disintegration of the artificially constructed disciplinary boundaries, so often linked to nationalist rhetoric, that have led us to work within intellectual enclaves. Terry Eagleton has suggested that the carnage of the First World War can be seen as an explanation for the rise within British universities of the study of English literature: "Eng lit," he says, "rode to power on the back of wartime nationalism" (30). But we could also say that across Europe in the nineteenth century, including within the British context, literary histories were being written to enshrine national perceptions. Writing in 1992, André Lefevere noted that: "Literary histories as they have been written until recently, have had little or no time for translations, since for the literary historian translation had to do with 'language' only, not with literature-another outgrowth of the 'monolingualization' of literary history by 
Romantic historiographers intent on creating 'national' literatures preferably as uncontaminated as possible from foreign influence" (39).

Lefevere called for translation to be relabelled "rewriting", of which more anon, and in his book Translation, Rewriting and the Manipulation of Literary Fame he looks at the multitude of social, economic and political factors that govern the production and reception of translations. What he identified was a notion of translation as "undesirable," as "contamination" from outside, translation as immigrant, since establishing the "aboriginal" credentials of a particular literature, certainly within the European context, was directly linked to the creation of a strong national identity. The literary historians he castigates were part of that process, seeking to establish the "roots" of a culture. Interestingly, that organic notion of "roots" that go deep into the earth means that having roots is then seen, metaphorically, as desirable. "Where are you from?" presupposes an answer that will reinforce rootedness: the answer will be that "I come from $\mathrm{x}$ or y, identifying a place, a space from which we can say we originate.

Or not, of course. Personally, I cannot answer "Where are you from?" without an explanation, and there are millions like me whose histories are not based on rootedness anywhere but on movement between places. Belonging, and belonging to a nation state or to a language, has acquired enormous significance, even in a world where so many people are in motion. And so many times the desirability of demonstrating belonging has had noxious effects. We can see this process at its crudest in discriminatory language policy, whether it is the banning of Welsh, Gaelic and Irish in British schools until well into the twentieth century, or of Spanish in the USA, as so many Chicano writers have recorded, or of Catalan, Basque and Galician in Franco's Spain, languages that are only now reviving and beginning to flourish not only orally but as literary languages, or of Slovene in Italy, as recorded by the extraordinary Slovene writer, 100 years old in 2013, Boris Pahor, whose book Necropolis has been described by Claudio Magris as comparable to the work of Primo Levi.

Ngugi Wa Thiong'o has written eloquently about his own search for rootedness in language, about being caught between Gikuyu and English, and about his personal journey from spoken Gikuyu to written English in his school years, then a rejection of English as a political statement, followed by a return to English via translation as he translates his written Gikuyu into English himself (20).

Ngugi's essay is very brief but very important, in that he is approaching translation from several different perspectives. Here is a boy who grew up learning the colonial language in order to further his education, a language in which he became able to exercise his prolific talents, a language he then fought against, seeing it as an instrument of oppression, but could then reconcile 
himself to it within a new context once it became the language into which he could translate his fiction. Translation here offered a means of moving between, of resolving the age-old dilemma inherent in translating between original and translation, source and target. What our future students may well note is the increased number of writers in the twenty-first century who also move around in between, some like Ngugi crossing backwards and forwards, some changing language to reinvent themselves in another language altogether, some who are maybe at second or third generation level, reinterpreting and questioning what is a mother-tongue, what does it mean to "belong" to a culture, a society, a place?

What our students are unlikely to do, though, is to attribute today's interest in translation to the emergence of translation studies as a discipline. Academic disciplines do not initiate anything, they follow on: physicists, poets, musicians, etc. are the people who initiate, and then others study what they have created, so our future students will see translation studies as yet another manifestation of the growing interest in translation, not as the cause. And indeed, translation studies today is becoming so diversified that there are now specialists working on aspects of translation so different from one another that they are not immediately mutually comprehensible. So, for example, there is some fascinating research being done into eye-tracking and interpreting, but this is light years away from considerations of the problems of translating a poem. Diversification of research is, of course, what happens when subjects start to grow, but to date so few people outside translation studies have even heard of the subject, that it can hardly be credited with changing very much. No, our students fifty years down the line will probably see today's interest in translation as a reflection of global uneasiness with ideas about definitions that seek to pigeon-hole the huge, unstable, swirling mass of questions around belonging, identity, and canonicity.

What our future students may well see, though, is something I think is discernible now, and that is the greater visibility of the translator him/herself, the translator as one of the key agents in the process of intertextual transmission. We have Lawrence Venuti to thank for highlighting the complex ideological implications of the translator's invisibility, and though we would probably all agree that translators are only just starting to become visible (I think of Star Trek and that instant of glittering particles when Captain Kirk and his team materialize somewhere or other on the way to becoming embodied), we do seem to be heading in that direction. What will undoubtedly become clearer in the future is how many writers who are not necessarily translators themselves are using translation or the figure of the translator in their fiction. Javier Marías' enigmatic protagonist in Un corazón tan blanco is an interpreter, and here, not 
for the first time, we see a parallel between the task of the translator in unravelling a mystery and that of the detective, searching for clues. Our future students will doubtless also be commenting on the global rise of detective fiction in the late twentieth and early twenty-first centuries, another phenomenon worthy of a lot more discussion. But let's now take a closer look at another novel, aptly entitled The Translator, by John Crowley.

The novel is set in the Cold War period, at the time of the Cuban Missile Crisis, when fears of a nuclear war started by the Russians were very real in the United States. The central characters are an exiled Russian poet, Falin, teaching at an American college, and an aspiring student writer, Christa. A relationship develops between them, centred on poetry and language: Falin is cut off from his own language, while Christa tries to learn Russian in order to read his poetry, but neither feels competent in the other's language. As she struggles to translate his work, he recognises the impossibility of the task: "A language," he said. "It is a world. My poems are written for the people of a world I have lost. To read them I think you must have lived in my world—my language — since childhood, and grown up in it" (163).

The poet and the student fall in love, but the relationship ends unhappily when he disappears. Years later, Christa, now a well-known writer herself, is invited to Moscow to a celebration of Falin's life (since glasnost he has been rehabilitated in absentia), because she has published some of the poems they worked on together: "Translations without originals" she had called them; poems neither his nor hers, or both his and hers; poems written in a language that she couldn't read, and surviving only in a language he couldn't write.

Crowley's novel highlights the paradox at the heart of translation: the intention behind translation is to bring to readers a text not available to those who do not understand the language in which it is written, to make it meaningful, to give it new life in a new language. Yet so much is left behind in any translation, because it simply cannot be fully transferred into another context. Christa cannot ever enter fully into Falin's linguistic universe, nor can he ever realise his Russian creativity in her language. The compromise is a text that is neither his, nor hers, that in some way belongs to both of them while belonging to neither. Christa's only option is to become Falin's rewriter, using the tools she has at her disposal and bringing her own creativity to her reading of his poems.

The Translator invites us to see translation as a collaboration, as a relationship between two people, one of whom wrote a text in one time and place, another who encountered that text and reconfigured it anew somewhere else. It also raises the basic question that has preoccupied poets and critics for generations, that is, what exactly is the relationship between so-called original and so-called translation. Octavio Paz (1992) sees what he terms translation and 
creation as "twin processes." In the one process, the poet chooses words and constructs a poem, which he defines as "a verbal object made of irreplaceable and immovable characters" (160). The translator takes that object, dismantles the linguistic signs, and then composes anew in his or her own language, producing another poem. Paz uses significant figurative language here: he sees the task of the translator as an act of liberation, for the translator's task is "freeing the signs into circulation, then returning them to language" (159). The creativity of poet and translator are parallel activities, the only distinction between them being that the poet starts with a blank sheet of paper while the translator starts with the traces of someone else's poem already written.

Paz is one of many poets who have re-evaluated the importance of translation and presented translators as creative artists in their own right. The Greek poet Nasos Vayenas has composed "Eight Positions on the Translation of Poetry," which has been translated by Paschalis Nikolau (2010). Vayenas' first position takes up the ideas of Walter Benjamin, set forth in his essay "The Task of the Translator," wherein he formulates the idea, which has since become so influential for translators and translation historians, that translation ensures the survival of a text by granting it an existence in another linguistic world. Vayenas asserts that in poetry, the word cannot be separated from its meaning, nor can signifier be separated from signified. This means that poetic language is an absolute language, which can be defined as "the non-translatable language" (130). He goes on to gloss this in his second position, where he proposes that translation should not be seen as a process of reconstruction of an original, since reconstruction implies using identical materials, but should rather be seen as a re-creation using new materials, those which are available to the translator in his or her language. In this respect, he is taking up a position almost identical to that of Octavio Paz. His third and fourth positions consist of just two sentences:

3. If translation of poetry is impossible, then the translation of poetry is a genuine art.

4. In translating poetry, the original is the experience, and the process of translation is the poetic act.

131

His remaining four positions highlight the significance of translation as a source of renewal for a literature, translation as a meticulous way of reading and the essential role played by translation in literary history. In his seventh position, he declares that some of the best Greek poems are translations while some translations are among the best Greek poems. His eighth position makes 
the crucial point that all literary systems contain translations, and this should be recognized: "A history of literature that excludes translations is an incomplete history. An anthology of poetry that does not include translations is an incomplete anthology" (132).

I imagine Matthew Arnold entertaining Vayenas to dinner in college at Oxford (though he studied at Balliol, he became a Fellow at Oriel, for those of you who want nitty-gritty detail), discussing Vayenas' proposition that translations must be included in any history of literature as fundamental texts in the development of that literature, along with Arnold's insistence on the inevitability of universal connections. They would probably have conversed in Greek-in Ancient Greek, of course-and it is just possible that as the evening wore on and the claret flowed, Arnold might have been persuaded to quote a few apposite lines from "Dover Beach," his moving poem about the sound of the sea by night, calling to mind the same existential doubts and fears that have troubled men and women through time:

\author{
Sophocles long ago \\ Heard it on the Aegean, and it brought \\ Into his mind the turbid ebb and flow \\ Of human misery; we \\ Find also in the sound a thought \\ Hearing it by this distant northern sea. \\ 144
}

Arnold is renowned as a critic, a poet, and also as a translator. He is also remembered for the bitter exchange with Francis Newman, his less eminent contemporary, about translating ancient Greek poetry. Newman's translation of The Iliad came out in 1856, with a preface in which he set out his ideas about Homer's style. Newman argued that Homer was a polymath and that his work was not always "at the same high pitch of poetry." Homer's style was "direct, popular, forcible, quaint, flowing garrulous ... similar to the old English ballad" (iv). Arnold was appalled by this. In his "On Translating Homer" (1861) he savaged Newman's ideas and Newman's translation. Poor Newmanwho was, after all, Professor of Poetry at Oxford—published a reply, "Homeric Translation in Theory and Practice" in 1861, protesting at Arnold's accusations, but Arnold trumped him with "Last Words on Translating Homer" in 1862, where he says that Newman is "perplexed by his knowledge of the philological aspect of Homer's language, encumbered by his own learning, Mr Newman, I say, misses the poetical aspect ... terrible learning, I cannot help in my turn exclaiming, terrible learning, which discovers so much!" (352). 
The debate between the two has been much discussed, but what matters here is that we have two opposing attitudes to translation, not so much domesticating versus foreignizing as rather a debate about readings of Homer. Newman acknowledged Homer's genius but saw him as so varied stylistically that the solution was to try and find an English poetic metre that would be, like Homer's, "fundamentally musical and popular." Moreover, given that Homer's language was archaic, Newman tried to produce an archaic effect, using the popular Victorian device of mock-medieval English ("thee" and "thou," "prithee," "verily," "I trow," etc.). Nonsense, said Arnold, not only does that sort of English sound terrible, it is absurd to try and reproduce how Homer may have been heard by his original audiences, because we can never know that. What matters is to produce a translation that reads as poetry for contemporary readers (contemporary readers with some acquaintance with the classics, of course), using plain, simple, intelligible and elegant language.

Of course seen with hindsight, the Arnold-Newman debate may appear like a rather inconsequential spat between two pompous Oxford men of letters, because neither sought to experiment with Homer and both were motivated by a spirit of respect and adulation. Nevertheless, where it remains important is that Arnold was objecting to what he saw as the downplaying of Homer as a poet. It is a view taken up in a different way by Ezra Pound, who famously remarked that a great age of literature is always a great age of translations. In his $A B C$ of Reading (1917), Pound declares that nobody can get an idea of Greek from reading translations, because there simply are no satisfactory translations. In his essay on "Early Translators of Homer" (1920) he proposes translations that could be sung or chanted, and in his typically trenchant manner calls for "more sense and less syntax" from Ancient Greek translators (273).

I use Pound a lot in my thinking about poetry and translation, for several reasons. He saw translation as a form of criticism, in that he highlighted the importance of reading as a vital first stage in translating anything. Also, he refused to be constrained by "faithfulness," claiming that what he terms an "honest" translation is the transparency of that translation which allows the reader to "see through to the original." And he was undeterred by criticism of the extent of his scholarly knowledge of the language from which he translated. I often lecture on Pound's Cathay, and several times questions from an audience concern the extent to which Pound was "unfaithful" to the Chinese and whether I condone such unfaithfulness. The answer I always give is that a) faithfulness is a criterion that fluctuates according to dominant stylistic norms and readerly expectations, and b) what he produced was beautiful as poetry in English. Every year, serving as judge for the Stephen Spender/Times poetry in translation 
prize, we judges are criticized for overstepping what some see as a frontier of unfaithfulness. But what we try to judge is the dialectic between the source poem and the translation, that is, does the poem work in English, and how does that poem relate to the poem it purports to be bringing across from its original language? We judge both the product and the process as materialised in that product, though of course we are privileged in that we are able to make a comparison. Readers who have no knowledge of any other language have to depend solely on the translation, so if a poem does not work as a poem, even if it can be seen as a close rendering of the original, then it fails. We have all read translations of poets who are regarded with awe in their own language but who come across in another language as weak, banal, wordy or unintelligible.

Which is the fault of the translator! Eliot Weinberger has put the case rather well. He quotes Mother Ann Lee of the Shakers, who declared that "Every force evolves a form." The force, or what Weinberger calls the "living matter" of a poem "functions somewhat like DNA, spinning out individual translations which are relatives, not clones, of the original. The relationship between original and translation is parent-child. And there are, inescapably, some translations that are overly attached to their originals, and others that are constantly rebelling" (110).

This is a good way to think of creative translation: as rebellion of a kind, at its extreme a form of patricide (or matricide) as Haraldo de Campos has playfully suggested about some of his translation work, but most productively, perhaps, as a challenge to established authority. Such a challenge can be highly creative as it takes from the source and recreates, that is, rewrites that source in another context. We could, of course, say that this is what translators have always been trying to do, but we would then have to acknowledge that all too often respect for the source takes such precedence that the translation becomes inevitably a merely derivative work. The secret skill is to produce a translation that can hold its own as a piece of literature, while at the same time acknowledging in some way the presence of a source elsewhere, no matter how remote that source has become. It is important to note, obviously, that if there is no source, then there can be no translation. Though I leave it open to debate as to whether there can be any text that is not, in some way, linked to a source somewhere else.

The contemporary Oxford classicist Stephen Harrison is particularly interested in the ways in which poets today are rewriting ancient texts. Bear in mind that in Arnold's day, all Oxford students (who were all men and all obliged to sign up to the 39 Articles of the Church of England) studied Latin and Greek, while today very few schools teach both Latin and Greek, which has meant 
that Classics has had to reinvent itself for the twenty-first century. There are wonderful courses around these days on the body in the Ancient World, on sexuality, art and architecture, social history - my son even studied Egyptian Middle Kingdom novels, which I never even knew existed! Stephen Harrison is interested in exploring how contemporary poets use ancient material, particularly since he too has noted the proliferation in many languages of writing and performance that draws upon classical Greek and Roman texts. Our students of the future will also have views on why so many European writers and artists have turned back to their ancient foundation texts in this postcolonial age. In an essay entitled "The Return of the Classics," Harrison notes how writers such as Ted Hughes and Joseph Brodsky returned to Ovid, how the figure of Electra recurs in Sylvia Plath's poetry, how Homer and Virgil recur in the work of contemporary Irish poets, and he adds that since 1960 some of the "most striking engagement with classical texts has come from writers outside the "traditional" English metropolitan cultural world, writers like Derek Walcott or Wole Soyinka or Margaret Atwood." Harrison puts the case like this:

Contemporary poets now turn to ancient material not so much in a spirit of homage as in a spirit of appropriation. The modern "deconsecration" of great poetic figures such as Homer and Virgil, in the sense of removing their cultural centrality as canonical and immutable texts generally known and read in their original languages, allows contemporary poets such as Derek Walcott or Seamus Heaney to create new classic works using classical material and a sophisticated intertextual approach, just as Virgil and Horace created great Latin works through the substantial and subtle reuse of Greek models in a Roman context. Poets can now safely appropriate what they need for their own work and their own contemporary concerns.

15

Lefevere would have used the term "rewriting" instead of appropriating, but the idea is the same. What Harrison also points out is that Virgil and Horace were effectively translators in their own time, for Roman classical literature, like classical sculpture, "translated" Greek models. Harrison refers to "substantial and subtle reuse," a good way of describing what happens in translation, given that complete equivalence is, as the poet and translator James Holmes put it some forty odd years ago, "perverse". Holmes made that comment in an essay where he drew attention to the impossibility of there being correspondence between the work of individual translators. He proposed giving five people a text, then giving each of those five texts to five more people and asking them to 
back-translate. His point was that you always have textual variations with such an experiment, so there can be no single "correct" version (1988).

Today we would say, well, yes, that's obvious, isn't it? Each individual brings their own individual reading to any text, a reading produced by their education, gender, language, nationality, religion, life experience generally. Let us digress for a moment to demonstrate this: the late British performance poet Bob Cobbing created a piece called "ABC in Sound" where, as he puts it in a note, much of the creative work must be done by the reader. The section on the letter M consists of 35 names, starting with McAllister and ending with McTaggart (1978). As one of my students said, "this is just a list of names from a phone directory," and of course it could be, though likely to have been a Scottish one given that every name is McSomething. But working in class with this text, no two students have the same reaction, because someone will have an association with a particular name, or someone will have no associations at all but be struck by the spelling Mc in some cases and Mac in others, while if there is a Scot in the class they will correct pronunciation (McGrath is pronounced McGraw, for example), and so what seems to be a banal list transforms into a creative event simply on account of the diversity of readings brought to the text by different individuals.

Could such a text be translated into another language, or is it totally culturespecific? The only way would be to play with the concept of a list of names that might mean different things to different people; in short, the only way to translate a text like this is to follow the strategy proposed by the German translation experts Hans Vermeer and Katharina Reiss (skopos or objective theory) and to rewrite the text in accordance with its function (2000). Though initially skopos theory was seen as relevant to non-literary texts (legal documents, instruction manuals, menus, etc.), that distinction breaks down once we stop considering literary translators as somehow more "bound" to the structures and language of the original.

A good example of skopos applied to literary texts is Adriana Hunter's translation of Frederic Beighbeder's novel satirizing consumerism in the world of French yuppies, 99 francs (2002). What Hunter did was to transpose to London all the Parisian references to trendy shops, restaurants, designer labels and so forth. She also adjusted the title of the novel, which appeared in English as 9.99. This is an extreme but clever example of domestication in translation, though since everywhere there is connection and cultural change cannot be halted, the coming of the Euro meant the disappearance of the franc, and hence the novel had to be retitled 14.99 euros.

But there is another way to think about the worldwide interest in translation. It is just possible that in fifty years' time the question will not be why was 
there so much interest in translation in the late twentieth and early twenty-first centuries, but rather: why was translation relegated to a secondary position in the literary hierarchy for so long, given its fundamental importance in the transmission of texts across cultures? Our future students may well see what is happening now not as some extraordinary new development, but simply as a return to a position where translation is recognised as a significant textual activity, recognition that has come with the challenges to canonization and with the advent of transnational literary historiography. Umberto Eco, a few years ago, wrote about "the new Middle Ages," a provocative idea that challenged the dominance of positivism and progressivism that has held sway since the Enlightenment. And indeed if we so much as glance at the Middle Ages, we find a constant flow of texts in and out of different languages, as writers borrowed forms, ideas, themes: Dante made his guide through the afterlife the Roman poet Virgil, Shakespeare took ideas for plays and poems from a whole range of sources. So when Harrison talks about the new spirit of "deconsecration" that writers today bring to their engagement with earlier writers, he is describing a healthy shift of perception that acknowledges that texts are not "immutable" but infinitely varied.

The Irish poet Michael Longley describes himself as "Homer-haunted for 50 years" (97). One of Longley's best-known poems is a sonnet, entitled "Ceasefire." This poem was published in the Irish Times the day after the declaration of a ceasefire by the IRA on 31 August 1994. Writing about the effect of this poem, Longley quotes another Irish poet, Nuala Ni Dhombnaill, who said that the effect of this poem "rippled through the community, both North and South" (105).

Yet Longley's poem is not overtly about contemporary Ireland at all; it is a translation of part of Book 24 of Homer's Iliad, most notably the moment when old King Priam of Troy goes to the Greek camp, to ask Achilles, the Greek hero who has slain his son Hector in battle, for the body. Achilles is moved by the old man, and agrees to the request and the two men eat together, in a temporary cessation of hostilities before Priam sets off back to Troy with Hector's body. Longley explains that he had been reading Book 24 and had the idea of compressing the 200 hundred lines of the scene into a short lyric poem as "my minuscule contribution to the peace process." He recounts how he played around with the sequence of events, in particular moving the moment when Priam kisses Achilles' hand, which happens at the start of their meeting in Homer, to the end of his poem. With that shift, he "inadvertently created a rhyming couplet," and then wrote the twelve lines that precede it. It is that couplet which still has the power to shock and which, read in the context of an end to the decades of violence in Northern Ireland, acquired such 
power. The words are voiced by King Priam himself: "I get down on my knees and do what must be done. / And kiss Achilles' hand, the killer of my son" (104).

Longley is quite clear that the source of his inspiration was the ancient Greek poet: "It was Homer who spoke to us across the millennia. I was only his mouthpiece" (105). Homer also spoke to the Australian writer David Malouf, whose novel, Ransom is also a retelling of Book 24, only now in another context, that of the global war on terror. Malouf relates in a postscript to the novel how he first encountered the story of the Trojan War when he was a boy, in the 1940s, in another time of war, the war in the Pacific. It is significant that these two contemporary writers chose to return to Homer as a way of writing about armed conflict in their own time.

A purist would say that neither Malouf nor Longley have produced faithful translations. Malouf has written a novel, added a new character, the peasant who accompanied Priam to the Greek camp and who is not in Homer at all, while Longley has reduced over two hundred lines to fourteen and has reversed the order of events. I would disagree with that purist: a translation is always a rewriting of a text, and in their very different ways both Longley and Malouf touch on what underpins Homer's epic poem, the pity and the terror of war. The task of the translator, as Walter Benjamin proposed in his seminal essay, is to give new life to a work in another time and place. Translation is so much more than the transfer of a text written in one language in to another, it is about recreation, regeneration, renewal, and this is why translation has always played such a key role in literary history.

We cannot conceive of World Literature without translation. In her book $\mathrm{Can}$ These Bones Live? Bella Brodzki argues that translation "underwrites all cultural transactions, from the most benign to the most venal" and asserts that just as we can no longer ignore the significance of gender, so we should not ignore the significance of translation (5). I add my voice to hers and propose that:

Translation is important because it compels us to reflect on what we understand by "origin" and "originality."

Translation is important because it reminds us of the infinite multiplicity of possible readings.

Translation is important because it forces us to think dialectically, because there is always a relationship between source and target readings and rewritings.

Translation is important because it reminds us of the transitory, shifting nature of aesthetic criteria, as what is deemed great in one age is so often dismissed in another. 
Translation is important because it exposes the absurdity of the idea of a definitive interpretation of any text. (Borges comes to mind here, commenting wryly that the idea of the definitive text belongs only to religion or exhaustion!)

Translation is important because it runs through discourses of intertextuality, global influence flows, transnational movement, canon formation and canon deconstruction, difference and différance.

Let me end with a little story. Revisiting Cape Cod after a dozen or so years, I was amazed to see warning signs about great white sharks on the Atlantic beaches near Truro where I had swum happily with my children. I asked for an explanation and was told that seals had moved in (and indeed, I saw several), possibly as a result of global warming, hence the sharks followed and there had been a couple of attacks, thankfully nothing fatal. That brought to mind something a marine scientist had once told me, which is that if we knew how many dangers lurked beneath the surface of the sea, we would probably never set foot in the water again. We choose to under-rate the dangers, choose to ignore what we cannot immediately see.

Which is what we have done with translation. We have under-rated the skills required to translate, underestimated the power of translation in intercultural communication, disregarded the vital role of the translator in bringing before us texts that we could not otherwise read at all, and, perhaps most significantly, overlooked the way in which translations have been a shaping force in literary and cultural history all over the world.

I would like to see the equivalent of those Cape Cod shark warning signs attached to all programmes, in World Literature, Comparative Literature and individual literatures, and my warning sign would read: Be aware! Here be translations.

\section{Works Cited}

Apter, Emily. The Translation Zone: A New Comparative Literature. Princeton: Princeton UP, 2006.

Arnold, Matthew. "On the Modern Element in Literature." In Poetry and Prose, ed. John Bryson and Matthew Arnold. London: Rupert Hart-Davis, 1857 [1954], 269-286.

Arnold, Matthew. “Dover Beach." In Matthew Arnold Poetry and Prose, ed. John Bryson. London: Rupert Hart-Davis, 1954, 144-45.

Arnold, Matthew. "On Translating Homer." In Matthew Arnold's Essays, Literary and Critical. London: Dent., 1861 [1906], 210-75. 
Arnold, Matthew. "Last Words on Translating Homer. A Reply to Francis W. Newman by Matthew Arnold." In Matthew Arnold's Essays, Literary and Critical.London: Dent, 1862[1906], 337-80.

Bassnett, Susan. Translation. London and New York: Routledge, 2013.

Bassnett, Susan. Translation Studies. 4th edition. London and New York: Routledge, 2014.

Benjamin, Walter. “The Task of the Translator." Trans. Harry Zohn. In Translation Theories from Dryden to Derrida, ed. Rainer Schulte and John Biguenet. Chicago: University of Chicago Press, 1992 [1923].

Borges, Jorge Luis. “The Homeric Versions." Trans. Eliot Weinberger. In Voice-Overs: Translation and Latin American Literature, ed. Daniel Balderston and Marcy E. Schwartz. Albany: State University of New York Press, 2002, 15-20.

Brodzki, Bella. Can These Bones Live? Translation, Survival and Cultural Memory. Stanford: Stanford UP, 2007 .

Cobbing, Bob. “АвC in Sound." In Alphabetical and Letter Poems. A Chrestomancy, ed. Peter Mayer. London: Menard Press, 1978.

Crowley, Tony. The Translator. New York: Harper Collins, 2002.

Eagleton, Terry. Literary Theory: An Introduction. Oxford: Blackwell, 1983.

Eco, Umberto. Travels in Hyperreality. Trans. William Weaver. London: Picador, 1987.

Harrison, Stephen, ed. Living Classics: Greece and Rome in Contemporary Poetry in English. Oxford: Oxford UP, 20og.

Hahn, David. "Editorial." In Other Words 41 (2013), 1-4.

Holmes, James. Translated! Papers on Literary Translation and Translation. Amsterdam: Rodopi, 1988.

Hunter, Adriana. £9.99. London: Picador, 2002.

Lefevere, André. Translation, Rewriting and the Manipulation of Literary Fame. London and New York: Routledge, 1992.

Longley, Michael. “Lapsed Classicist.” In Living Classics: Greece and Rome in Contemporary Poetry in English, ed. Stephen Harrison. Oxford: Oxford UP, 2009, 97-113.

Malouf, David. Ransom. Sydney: Knopf, 2009.

Newman, Francis. "Preface." In The Iliad of Homer: Faithfully Translated into Unrhymed English Metre. London: Walton and Maberly, 1856, iii-xx.

Ngugi wa Thiong'o. "My life between Languages." Translation Studies 2: 1 (2009), 1721.

Paz, Octavio. "Translation, Literature and Letters." Trans. Irene del Coral. In Theories of Translation from Dryden to Derrida, ed. Rainer Schulte and John Biguenet. Chicago: University of Chicago Press, 1992, 152-162.

Pound, Ezra. An A BC of Reading. London: Faber and Faber, 1968 [1921].

Pound, Ezra. "Elizabethan Classicists." In Literary Essays of Ezra Pound. New York: New Directions, 1968 [1917], 227-248. 
Pound, Ezra. "Translators of Greek: Early Translators of Homer." In Literary Essays of Ezra Pound. New York: New Directions, 1968 [1920], 249-79.

Vayenas, Nasos. The Perfect Order: Selected Poems 1974-2010. Selected and trans. by Richard Berengarten and Paschalis Nikolaou. London: Anvil, 2010.

Vermeer, Hans. "Skopos and Transmission in Translational Action." In The Translation Studies Reader, ed. Lawrence Venuti. London and New York: Routledge, 2000, 221232.

Vieira, Else, and Bernard McQuirk, eds. Haraldo de Campos in Conversation: In Memoriam. London: Zoilus Press, 2009.

Weinberger, Eliot. "Anonymous Sources: A Talk on Translators and Translation." In Voice-Overs: Translation and Latin American Literature, ed. Daniel Balderstone and Marcy E. Schwartz. Albany: State University of New York Press, 2002, 104-118. 